Journal of Development and Communication Studies

Vol. 5. No. 1, July 2016 - June 2017 ISSN (Online \& Print): 2305-7432.

http://www.devcomsjournalmw.org.

\title{
Imperial Britain and the challenge of press freedom in Nigeria during the Second World War
}

Emmanuel Nwafor Mordi, Department of History E International Studies, Delta State University, Abraka, Nigeria.Email: emmanumordi@gmail.com

\begin{abstract}
The imperial power, Britain, was in a quandary over the extent of press freedom to allow in Nigeria, its largest black African colony, during the Second World War. This fundamental issue so emphasized by Allied propagandists as one of the freedoms for which the world was at war has not yet received scholarly attention and is investigated in this study. The colonial state so much pressurized the local press that the latter had walked a tight rope throughout the duration of the war. An anti press freedom enactment which took effect on the declaration of war had foreshadowed the muffling of freedom of expression at a critical period of Nigerian history when the press was the only viable avenue open to colonized Nigerians to ventilate war induced grievances. This historical study applies the critical evaluative methodology built on archival sources, including the newspapers in the repositories of the Nigerian National Archives, Ibadan and the University of Ibadan Library to expand the cumulative knowledge of Nigerian media history. It concludes that the Nigerian press exploited loopholes in the censorship regulations, the palpable support of the newspaper publishers for Allied victory, and the restraining influence of the Colonial Office, to articulate Nigerian grievances and evade the colonial sledge hammer. The latter situation was only reversed when the colonial state enforced full press censorship after the European phase of the war as its strategy of stemming the rising tempo of militant nationalism in wartime Nigeria.
\end{abstract}

Key words: Nigerian media history, press freedom, Second World War, British colonialism, militant nationalism.

To cite this article: Mordi, E.N. (2017). Imperial Britain and the challenge of press freedom in Nigeria during the Second World War

Journal of Development and Communication Studies, 5(1): 98-121.

https://dx.doi.org/10.4314/jdcs.v5i1.6

\section{Introduction}

This article examines sustained attempts by the colonial state to muzzle press freedom in Nigeria, Britain's largest African colony during 
the Second World War, 1939-45 by the Imperial power .Though the war was largely a European affair, but Nigeria was constrained to fight in defence of its colonial master, despite the colony's safe distance away from the war theatre. Indeed, at the onset of the Second World War in 1939, the Nigerian press, reflecting the mood and inclination of the educated elite, had mobilized Nigerians to support Imperial Britain. On 25 May 1940, the influential West Africa magazine explained that the Nigerian supported Britain because of his appreciation that a German victory "would sound the death-knell of all his legitimate aspirations," including the rational expectations of the emergent elite that the end of hostilities would not only open up the political space but also facilitate their involvement in the management of Nigerian affairs. In the absence of a viable nationalist movement until 1944, when the National Council of Nigeria and the Cameroons (NCNC) was formed, the articulation of Nigerian political aspirations and interests during the period was effected through the medium of the local press (Mordi, 2009). In the circumstance, the imposition of press censorship had the potential to muzzle the expression of Nigerians' yearnings for freedom.

It is thus necessary to explicate the contradictions inherent in an emergency situation which demanded the diplomacy of a colonial power to harness and sustain the spontaneous loyalty of a subject population, but which became an occasion for the exercise of the show of force and defiance. Given the spontaneous support of the press and indeed Nigerians for Imperial Britain's victory over Nazi Germany, why did officialdom adopt measures which threatened to erode the goodwill of Nigerians? Why and how did the press strive to sustain its freedom in the circumstance of wartime when the colonial state wielded enormous emergency powers to compel obedience to its will and policies? What was the impact of the concomitant mutual breach of trust and antagonism by the two institutions on the sustenance of the support of Nigerians for wartime measures in the face of evidence of racial discrimination? Finally, given the profound impact of the war on the ideology of colonialism, how successful was the colonial state in managing Nigerians' yearnings for freedom, even in wartime, which they ventilated through the medium of the press?

Extant studies of Nigeria during the Second World War have focused on the role of Nnamdi Azikiwe, Nigeria's American-educated journalist and foremost nationalist of the World War II and post war era who published the famous West African Pilot in 1937, after an eventful journalistic stint in the Gold Coast (Jones-Quartey, 1965; Azikiwe, 1994; Olisa \&Ikejiani-Clarke, eds.1989). Azikiwe is noted to have introduced "an entirely new chapter in journalism" through which he "contributed in a very large way towards influencing thought in Nigeria" (Ikoli, 1950:627). Azikiwe's journalism had thus brought for the first time "into the stream of national consciousness through a popular press", elements who were previously "largely ignored by other leaders or else 
underrated" (Jones-Quartey, 1965:153), and significantly spread political consciousness and ideas of nationalism in the Nigerian interior (Coleman, 1958).

Recent studies have sought, however, to emphasize that Nigerian initiative prompted Britain's reluctant adoption of wartime propaganda to keep Nigerians in a war mood, but which on the long run, turned out to be an abysmal failure (Mordi, 2009), and led to the rigorous pursuit of post war propaganda as an instrument to contain surging post war militant nationalism in Nigeria (Mordi, 2011). The latter studies merely make passing references to the attempts of colonial officialdom to censor the press in wartime. The false impression has thus been recycled by scholars who have studied the press after Omu (1978), probably due to lack of original data, that threat to press freedom in colonial Nigeria ended with the seditious offences ordinance of 1876 as subsequently amended in 1909, 1916, 1942 and 1954, as well as the newspaper ordinance of 1903, amended in 1917, 1941, and 1954. These had sought to severely limit press freedom in colonial Nigeria by penalizing the preaching of hatred against the colonial government, as well as different classes or races in Nigeria (Agbaje, 1992; Okonkwor, 1989).

As a consequence, the sustained pressure of the colonial regime which made the press to walk a tight rope throughout the duration of the war remains neglected. This current enquiry helps shed some light on it, given Hachten's (1971:67) generalized assertion that the activities of Africa's colonial press "were often circumscribed by restraints imposed by colonial authorities". Certainly, an examination of wartime censorship in Nigeria brings new insights into press control in important British colonies, and so offers a contribution to our understanding of both colonial government and wartime censorship. It is thus the objective of this essay to expand the cumulative knowledge of Nigerian media history, by exploring press censorship in Nigeria during the Second World War. The paper seeks to argue for the proposition that the Nigerian press successfully resisted the censorship regulations imposed by British colonial overlords, until the end of the war when the colonial state clamped down on the Zik press in a bid to stem the rising tempo of nationalism, purveyed by the latter.

\section{Methodology}

The paper adopts the critical evaluative historical methodology built on primary, archival sources. These include colonial government official publications, memoranda, reports, minutes, legislative council proceedings, specific enactments, censorship regulations, despatches, as well as newspapers which are available at the Nigerian National Archives, Ibadan and the University of Ibadan Library. Three national dailies were studied (Coker, 1965). These were Azikiwe's West African Pilot, published in 1937(Azikiwe, 1994); Nigerian Youth Movement's Daily Service, first published in June, 1938, as a daily organ of the body 
(Ikoli, 1950), suspended in October, 1938 until 1June1940, when it made a new start, and the Nigerian Daily Times, published in 1926 by private Nigerian and European interests, with Ernest Ikoli as its first editor, but which during the war identified with Nigerian aspirations (Jose, 1987). Provincial newspapers "did not make any noteworthy contributions to the advancement of political ideas or to resolution of political controversies" during the period (Omu, 1978; Oduntan, 2009:27), and have, therefore, received no attention in this study. Of importance, however, are contemporary publications as well as secondary sources provided by peer-reviewed articles and books. The identified sources were consulted and interrogated for their credibility, validity, reliability and relevance to the subject of enquiry. They served as the building block for reconstructing, explicating and writing the history of the subject of study, using the critical-evaluative tool of the historian which is built on a narrative frame work so as to clearly establish the trends and patterns of the episode in the historian's evocative prose.

\section{Press censorship regulations during the Second World War}

In the aftermath of the Second World War, the first session of the United Nations General Assembly, in 1946, as cited by Mendel (n.d.), proclaimed that freedom of expression, or broadly "Freedom of information is a fundamental human right and...the touchstone of all the freedoms to which the United Nations is consecrated"(2). This freedom is neither absolute nor the exclusive preserve of the press, but in its early application was used interchangeably with the freedom of the press. It can be restricted by law in the overall legitimate, overriding societal interest, without discrimination, but inherent in it is the right to seek, obtain, disseminate and impart information, including that in the custody of public bodies, thereby promoting diversity and vitiating the tendency towards the concentration of media ownership in a few hands. Press freedom is now viewed from both constitutional and normative perspectives, but it is important to note that journalists' defence against press censorship is hinged on their right to freedom of expression. Indeed, press freedom does not constitute a legal right in Britain, where the press is not singled out for entitlement to the enjoyment of special privileges distinct from those of free speech, free expression, and free communication. Yet, it is generally agreed that implicit in press freedom is the independence and freedom of all media of communication from all forms of direct government control (Tambini,2012).

Ordinarily, then, the free press, which acts as a watchdog on kings, lords and commons, and functions as a Fourth Estate, is one that is free to make enquiries without legal inhibitions (Martin, 1947). But, as Broughton (1961) rightly observes, press freedom relates closely to the exercise of discretion by editors and editorial executives in limiting the choices they make as to "what goes in and what stays out of the 
newspapers under their authority" (35), in deference to the dictates of public obligation and duty. The key concepts are thus autonomy, personal integrity of journalists, and media self determination in relation to the content of the news media, as against its determination by the government or the public (Twumasi, 1981). In reality, thus there are several impediments, even in democratic societies, notably Britain and the United States of America to the freedom of the press. These include the laws of libel, trespass, slander, contempt of court, confidence, copyright, of parliamentary privileges and the Official Secrets Act, which curtail even the ordinary citizen's rights to free speech and to free enquiry (Trewin, 1975; Tebbel, 1968). Such restrictions are often seriously enforced in troubled times, when people in authority become obsessed with concerns about measures and attitudes that would not stir up trouble or rock the boat.

The Second World War years in colonial Nigeria were such troubled times. As expected, the colonial government enacted restrictive press regulations when, on 30 August 1939, barely four days to the outbreak of the war, Governor Henry Bernard Bourdillon of Nigeria issued the Defence Regulations under the Emergency Powers Regulations 1939. The provisions of the regulations were derived from the Empire-wide Emergency Powers Colonial Defence Order in Council of 1939. The order was meant to be implemented simultaneously with Britain's formal declaration of war against Germany. It had empowered His Majesty to take all necessary and expedient steps that would enable him to effectively and successfully prosecute the war and ensure not only the supply of essential services and commodities to the population but also secure public order and safety. The regulations contained drastic, comprehensive measures, with the potential to severely restrict press freedom in wartime Nigeria. The provisions of the regulations were so elastic that they could be interpreted willy-nilly to implicate the press. The press was required to take measures not to contravene the regulations, by voluntarily submitting any matter over which it had doubts for pre-publication censorship. As the West African Pilot aptly noted on 16 September 1944, the only option open to the press was to obtain the permission of the government to publish such matter without pre-publication censorship, and bear the consequences of its gambit.

Part II of the Defence Regulations, namely Censorship and the Control and Suppression of Publications, Writings, Plans, Photographs, Communications and Means of Communications, formally instituted press censorship in war time Nigeria, with respect to printed matter of all descriptions. The Chief Secretary to the Government was appointed the Press Censor, under who was the general control of press censorship. He exercised this responsibility in the colonial capital, Lagos through an officer deputed by him to act in his name wherever he so signified, by notice. The law also appointed assistant press censors for Nigeria's Calabar and Owerri Provinces, where they were represented by the 
Residents based in Calabar and Port-Harcourt, respectively to whom all matter printed in their respective provinces had to be submitted for censorship. Outside the two provinces, all printed matter meant for censorship had to be submitted to the press censor in Lagos. The regulations wholly prohibited all publications relating to military strategy, the conduct of war, as well as publications deemed to be calculated to lower troops' morale or discipline or prejudice the recruiting of soldiers or encourage, or create disaffection among any section of the population within the colonial empire. The law permitted the press to voluntarily submit in triplicate to the press censors all matter before publication, either manuscript or in proof. The press censor would return his verdict in any one of three ways:

(a) No objection seen to publication.

(b) Responsibility for publication must rest with the publisher.

(c) Must not be published.

In the case of photographs or other pictorial matter, the law required that they be submitted in triplicate to the press censor, who was empowered to either "pass", "stop", or pass subject to blocking of some details believed to have the potential to give useful information to the enemy. The law also prohibited persons from publishing or reciting any statement or reports about the war made by other people, whether written or verbal, which were considered to have the potential to create alarm or despondency in the minds of those who heard or learnt of them (NAI, GR/ X18 Government Printer 1944 ).

The press accepted to be guided by these stringent regulations, which it considered as normal, for three reasons. First, like the Defence of the Realm Act of the First World War (Osuntokun, 1979), the press viewed the regulations in question as temporary measures that would be terminated at the cessation of the war which had necessitated them. Two, as the West African Pilot enjoined its readers on 16 September 1944, wars generally necessitate the sacrifice of certain liberties as part of the general contribution to victory. Three, the press adopted the view propagated by Allied propagandists that Britain was forced into the war to defend world freedom and democracy against Nazism, and deserved the support of all peoples to succeed.

In adopting this position, the press was encouraged by Governor Bourdillon's assurance on his assumption of office as Nigeria's colonial governor in 1935 which the Daily Service recalled on 13 October 1938 that the government would always take the people into confidence in all its actions. Thus the press publicized with anxiety, pronouncements of European dictators and other overwhelming evidence of intensive war preparations in Europe which had heightened tension across the globe, and assured the colonial authority that Nigerians were ready for the great sacrifice, demanded by the defence of the Empire (Mordi, 2009). Nigerians so publicly demonstrated their loyalty to Britain and readiness for sacrifice that Governor Bourdillon openly acknowledged in West 
Africa, 25 May 1940 that Nigerian loyalty had "been continuing to make itself manifest to me during my three and a half years as Governor".

It is important to emphasize that the press censorship regime in Nigeria during the Second World War derived its basis from developments in the metropolitan capital. One new department which the war brought forth in Britain in September 1939 was the Ministry of Information, which was saddled with the responsibility of distributing all information related to the war as well as with news censorship. As with Part II of the Censorship Regulations outlined above, the major plank of the metropolitan press censorship was the "principle of selfenforcement" whereby newspapers were issued with guidelines about stories likely to infringe the regulations. Newspapers submitted their stories to the censor who scrutinised them and removed any piece of information which was likely to be prejudicial to the success of Allied military operations, and conversely of assistance to the enemy. Changes were indicated in blue pencil, or the story was returned with an official stamp as a mark of its approval for publication without any change. It was an offence liable to prosecution to publish a story that was not "Passed for Censorship". Even reports directly emanating from the Ministry of Information had to be censored before their release with a view to striking a balance between press freedom and 'national interest'. In the early stages of its implementation the policy was discredited by much chaos and confusion from the ministry which led a section of the British press to accuse the Imperial Government of acting in a Gestapo manner, and $30 \%$ of the British adult population to turn to Radio Hamburg, a Nazi propaganda outfit for information about the war. The aftermath of the ensuing national debate was the stripping of the Ministry of Information of the power to issue and censor news, a role that was vested in a new independent Press and Censorship Bureau. The BBC also became adopted as the Imperial Government's official broadcast channel, often with directives on how to present news of the war in a positive light. A reorganised Ministry of Information improved relations between the government and the press, having devised a new censorship formula auto-imposed on editors who sought permission from the Censorship Division with respect to sensitive issues. Yet, contrary to its reputation for liberalism Britain under Winston Churchill suppressed ten newspapers which sought to mobilise opinion against the war effort (Irvin, 2014; Anton).

\section{Voluntary censorship}

In Nigeria, on the eve of the declaration of war in 1939, a small information office which was manned by an Assistant Secretary was established in the Nigerian Secretariat. His duty was to sort and distribute matter which was supplied to him by the metropolitan Ministry of Information. Mordi (2009) notes that a new information 
officer was subsequently appointed to distribute, through the press and related channels authentic information on the progress of the war to the public. The enthusiasm of the press was, however, dampened by the negative official attitude to Nigerians' demonstration of their willingness to be enlisted to fight on the side of Britain. The press alleged racial discrimination, and openly questioned government's attitude, as captured by the Daily Service of 6 July 1940:

Does the Nigerian Government regard this war as a white man's affair in which the African people are required to take only a passive interest, or do they sincerely believe that the present struggle concerns black and white subjects of the crown alike, and that early success would depend upon all of us getting down grimly to the task together...? In all matters concerning military activities, there is a tendency to pass over the African as if he does not exist...

Press' allegations and complaints about racial discrimination in wartime Nigeria were indeed, not unfounded. In fact, racial discrimination tended to permeate every facet of the colonial state. Thus a wartime instruction issued to white troops in West Africa emphasized the need to preserve white superiority: "The British are looked up to, put on a very high level. Don't bring that level down by undue familiarity". Killingray (2010) further shows that "Race was a determining element in the command and order of the British African colonial forces" (84). The press had adopted the position that the relaxation of the old fashioned imperialist rule which forbade the white official from fraternizing with the Africans would help rather than destroy the white man's prestige. So too, would the scrapping of such obvious disparities institutionalized as "European post" , "European Quarters" , "European Hospital” , "African Surveyors" , "African Hospital" , etc, that tended "to make more acute the wave of racial antagonism" .The press, though not unmindful of government's ban on open discussion of the issue of racial discrimination, chose to bring the matter to the notice of Nigeria's new, 58-year-old Governor Arthur Frederick Richards, who was inaugurated in office in December, 1943. This was given the fact, as aptly editorialized by the Daily Service, on 5 January 1944, that the "deepening sense of mutual contempt of colour is the greatest single disruptive factor to the British Commonwealth of Nations".

In spite of this overwhelming evidence of racial discrimination in wartime Nigeria, government sought to discredit media reports of them as half-baked and ill-digested, and designed to give direct help to the enemy. Consequently, government reminded editors of their duty under the Emergency Regulations, to submit to the system of voluntary censorship as was the practice in England, or in the alternative, compel government to enforce censorship before publication. Government did 
not enforce pre-publication censorship because, in the words of a Daily Service editorial of 5 January 1944, it "will be a great nuisance to the Government", and "a greater nuisance still to the proprietors of the newspapers" who should accept responsibility if the law had to be enforced in future.

Government's reluctance to enforce full pre-publication censorship derived from the fact that the publishers of the newspapers were fully supportive of the war, which they had clearly demonstrated in the columns of their newspapers. The press had adopted the view that it would be totally wrong to misconstrue the legitimate complaints against the acts of indiscretion of a very tiny fraction of European officials as inciting racial ill-will in Nigeria, given what the Daily Service of 26 August 1940 aptly described as "expressions of unreserved loyalty and burning desire" of the publishers of the newspapers "to support the government to the limit of their ability and resources in the general war effort".

Besides, both the press and the colonial government appreciated the need for some moderation. The press was conscious of its role as watchdog and medium of education and enlightenment, even in wartime. This placed a responsibility on it to call attention to actions of any "blundering official" that could create resentment of government actions. The West African Pilot of 22 June 1944 thus enjoined government officials to welcome "...fair, honest and well intentioned criticism", rather than drive underground discontent which would "break out later in more virulent form". Above all, the press was committed to its higher obligation to serve the highest interest of thousands of helpless, inarticulate colonial subjects who looked up to it to protect, uphold and champion their cause. To fail in such a duty, editorialized the Daily Service of 30 January 1941, would amount to "the greatest crime of our age". On this score, the press was not ready for compromise. H.O Davies, NYM Secretary General made the point so explicitly in his regular column in the Daily Service of 28 August 1940: "As for us, our path is beaten,-Victory for the Commonwealth, justice and progress for our people, and truth, at whatever cost".

A balancing act was thus called forth on the part of the press, and the colonial state. First, in order not to breach the censorship regulations, and provide the press censor with an opportunity to wield his "heavy blue pencil" against their newspapers, Azikiwe in his Inside Stuff column in the West African Pilot of 4 March 1940 disclosed that editors devised ways of being "very discreet" in the discharge of their duties. They did so by allowing their subordinates to oversee the affairs of newspapers, while they travelled out of their duty posts. A notable example was Nnamdi Azikiwe, who left the Pilot, off and on, in charge of his lieutenants, trained by him. Some of them were "able to hold the forte, as best as they could, during my short respite and absence". A corollary to this is for the editor to avoid punishment by currying favour 
and reward from the establishment, in return for diluting the pungency of his editorials, or simply omitting, distorting, and adopting "rhetorical devices" rather than reporting contentious issues in obvious acquiescence to self-censorship(Lee,1998:57). Thus during the war Azikiwe, the publisher and editor of the Pilot, as well as executive committee members of the Nigerian Youth Movement (NYM), publishers of the Daily Service, including H.O. Davies (Business Manager of the newspaper and NYM Secretary General up to 1941),Ernest Ikoli(NYM President, and editor of the newspaper up to 1943) , and Samuel Ladoke Akintola(editor of the newspaper from 1943 to the end of the war) enjoyed sundry favours from the colonial state, with dire consequences for the credibility of their newspapers(Mordi, 2008,2009,2011,2012).

Second, Azikiwe further disclosed in his popular Inside Stuff column in the West African Pilot of 18 March 1940 that editors were constrained to choose between publishing information about the war or war news based on "the 'handouts' which the Ministry of Information and the British Official Wireless Service release to different Newspapers of the Colonial Empire," and remaining silent. However, these were so "standardized and stereotyped" that the newspaper became dry and drab ,in spite of the facilities available to the press to gather news from across the globe, because editors considered the official handout "nothing of consequence to report". The colonial government also tended to slow down the proliferation of newspapers outside its control during the period, using the newsprint weapon as a form of disguised censorship. To this end, a law which banned the importation of newsprint was brought into being in 1941(Government Printer 1941, Control). Governor Bourdillon applied the law in 1942, to decline approval to Azikiwe's request for permission to publish newspapers in Kano, Ibadan and Jos, in spite of his readiness to make an alternative arrangement to import newsprint without offending the Defence Regulations. The government had attributed its decision to the shortage of newsprint, arising from "heavy American war insurance risks and increased production costs" which led to "increase in the prices of newsprint" (CSO 1/32, Ending December 1942). Yet, as the West African Pilot complained on 24 June 1944 government published its own newspaper during the period, the Nigeria Review, "fully funded by government", and "relying neither on sales nor advertisements". It was a medium to disseminate war news, whose annual circulation figure increased from its initial 480,000 in 1942 to 1,497,150 in 1945 despite newsprint scarcity (Mordi, 2009:245). In spite of this, newsprint regulation remained in force for the Nigerian press, even long after the war, until 1948, when control was temporarily removed from all types of paper, excluding newsprint and cover paper (Government Printer 1949, Vol. ii). 
Outright prohibition of publication of news and information, or directives to editors "supplied personally and confidentially" (CSO 1/32 December, 1942), to desist from further publication of news or review of certain publications in the press, also characterized the regime of press censorship in wartime Nigeria. For instance, the workers' strike of $1941 / 42$, to press for the award of cost of living allowance (C.O.L.A.) and a general wage review to cushion the effect of war induced inflation on them, attracted drastic actions against the press and M. A.O. Imoudu, leader of the Railway Workers' Union (Oyemakinde, 1974), for supporting and actively participating in the workers' action. On 23 January 1942, the governor restricted Imoudu from Lagos to Auchi in Kukuruku Division of the Benin Province, a distance of 441 kilometres, and as the West African Pilot disclosed on 30 September 1944 forbade the press from publishing any news or comment about the restriction. The restriction of Imoudu thus preceded the governor's publication of a Gazette on 4 February 1942, conferring on him power to prohibit and penalize publications about labour unrest, food shortages and related issues, which he had cause to believe might raise the morale of the enemy, provided he obtained a certificate from the Chief Secretary to the Government as proof of his belief. The governor's opinion thereby usurped the power conferred on the courts by the Nigeria General Regulations of September 1941 to determine such prosecutions (Mordi, 2002:22).

Also prohibited at the onset of the war were all publications and records of the Watch Tower Bible and Tract Society (Government Printer, 1940). In 1941, the government enforced this prohibition order and seized and confiscated all publications of the group which were already in circulation in Nigeria on the grounds that they contained "seditious and subversive propaganda" (Council Debates, 24th Session 1946).The prohibition was enforced throughout the duration of the war, even though some colonial administrators had viewed Jehovah's Witnesses as "Harmless fanatics". The enforcement could be due to the group's indiscretion in wartime of putting "God higer (sic) than the State" and committing itself to "oneness of mind and purpose and devotion to...God's kingdom and its righteousness" in its fight "for the New World and its interests", rather than for the victory of Britain and its allies over Germany (W.R. Brown to Denton, 29/6/44, No. 56).

The governor, in September 1944, also barred the press from further serializing a pamphlet, which in obvious reference to the exploitative and discriminatory activities of European firms operating under the canopy of the Association of West African Merchants (AWAM) had been critical of a tendency towards a virtual monopoly in Nigeria. Of the activities of the AWAM, Coleman(1958) has observed that the "near-totality of economic power exercised by a small group of European firms, together with apparent governmental support or toleration of that power, gave rise to a popular image of alien collusion 
and exploitation" (81). A similar image of collusion could be seen in the King's College Incident, when the government instructed the press never to make any comment on the arrest and arraignment of 75 students of King's College, Lagos, who had protested at the conditions of their school's temporary accommodation, in 1944.Though the magistrate court subsequently dismissed the case, but the colonial authorities conscripted eight of the boys into the army(Killingray,2010:50). One of the studentconscripts, Samuel Oparaocha had subsequently died at the Enugu Army Hospital, in Nigeria's colonial Eastern Provinces, and generated controversies (Niven to Akintola, 1944, No. 56/382).

The West African Pilot on 16 September 1944 thus rightly wondered how publication of news or comments on these issues could be reasonably said to "affect the security of Nigeria, speaking from a military point of view", but to no effect. Such complaints from the press over government infractions on their freedom, notwithstanding, editors often consulted the Public Relations Officer when in doubt as to the advisability of publishing certain articles, and they invariably took the advice they were given. In the cases of the King's College incident and the Imoudu restriction they complied with the directive to refrain from comment, even though they subsequently suggested that the news had been suppressed (Oyo Prof 2/3 No. 60/1944).

Government's frequent threats to amend, or enforce the censorship regulations, and the focus of such threats and amendments on the capacity of information purveyed by the press to excite racial ill will and ill feeling, and boost the morale of the enemy reflected government's sensitivity to the issue of racial discrimination. Though it enjoyed official backing, the colonial government was most uncomfortable about racial discrimination being publicized on the pages of newspapers. Certainly, the colonial authorities were anxious to shield the subject population from the effect of hearing "the denunciations of the methods of their colonial rulers from German propaganda and attacks on the British by the Vichy French" (Crowder, 1974:611), which emanated from American and Soviet sources. In furtherance of this, the colonial government of Nigeria, apart from the enactments in question, distributed a list of do's and don'ts to the press, which the Daily Service of 18 June 1940 duly publicized, notably:

Don't pay attention to any news that is not official and therefore not authentic. Don't be misled by anything you hear in justification of Nazi or Fascist methods. The reaction "But there's something in what they say" is the reaction they want. It's attitude of mind they are trying to induce. Do leave your disputes and your agitations for change until after the war. Criticism of a government in wartime actually helps the enemy... 
The governor's sensitivity to press comments and reports could also be attributed to the nationalist sentiments, which the press thereby purveyed and encouraged. The war had exploded old myths about the invincibility of Imperial Britain and about racial superiority, and opened the eyes of the colonized to the possibility of self government. The fall of Malaya had "struck a severe blow to white prestige throughout the nonEuropean world" (Coleman, 1958:231), and cast serious doubts about the capability of Imperial Britain to defend and protect its African subjects. So precarious was the British military position in the Far East that not only did African troops rally to the support, if not rescue of the embattled imperial power but also "for the first time the administration appealed for the loyalty of their subjects rather than assumed it for granted". Indeed "The myth of British imperial invincibility was shattered in the eyes of educated Africans with the conquest of Britain's Far Eastern colonies by the Japanese, a coloured race". Also, "forever shattered" was "White supremacy, coupled with the hitherto monolithic structure of colonial rule" (Crowder, 1976:612). Africans were, in fact, rudely awakened to the fact that self-government could be won, even if constitutionally. The colonial government, in such circumstances, refrained from taking any drastic action against their newspapers.

\section{The restraining influence of the Colonial Office}

The colonial regime, especially under Sir Bernard Bourdillon would seem to have acted within the ambit of laid down policy in its frequent threats and actual attempts to censor reports of acts of racial discrimination. Similar reports were censored in the United States of America, and in other parts of the British Empire. The rationale was to discredit the impression that "racial discrimination was the policy of the Empire", and received official endorsement. It was feared that too much focus on incidents of racial discrimination could not be "calculated to improve relations between Africans and Europeans", in Nigeria, where majority of the people were illiterate and not exposed beyond the "hills around their villages" (Denton, 1/140 No. 103, 1940).

Indeed, government tended to exaggerate the influence of the power of the written word purveyed by the press on Africans, and hinged its hypersensitivity to press criticisms of racial discrimination on the susceptibility of ignorant Africans to believe everything in print. The argument, as articulated by the Nigerian Daily Times on 17 June 1938, seems to be that "the power of the press is in inverse ratio to the literacy of the public" such that "The more unenlightened the people are, the greater is their belief in the written word". In this assertion, the contradiction inherent in the narrative of illiterates reading and believing the written word is lost sight of. The West African Pilot on 21 September 1938 thus objected to "a wholesale condemnation of educated and intelligent African men and women ...as 'semi-educated' and 'semiliterate', despite their academic and professional qualifications in Europe 
and America". The European was thereby encouraged in "the assumption of airs of superiority to the African". Omu (1968) dates this tendency to the end of the First World War, when colonial authorities strove to curb press freedom because of their assumption that the written word could inflame Africans to undermine "the basis of colonial power" (280), despite the evidence that "people as a rule attend to communications not... to learn something or reconsider their own philosophies of life ..." (Encyclopaedia Britannica, 15:36-45).

Besides, the evidence does not support the suggestion that high level of illiteracy is a justification for the enforcement of press censorship, which is also imposed even in the most literate, democratic countries of the world. For instance, the act of "managed news", leading to "credibility gap" in the United States of America is "as old as the federal government itself" and has pervaded all administrations (Krieghbaum, 1968:59). In fact, press censorship is no respecter of literacy, ethnicity or race. Rather, as Basowitz (cited by Stein, 1968) aptly observes, press censorship is partly induced by a feeling of guilt about our inability to resolve certain problems, whose existence we then seek to deny. Since "The communications media, in reporting the news, confronts us with the continual presence of these problems and thus become agents which disturb the tranquillity for which we yearn" (77), they are censored.

Thus Governor Bourdillon strained to assure Lord Moyne, Secretary of State for the Colonies in September 1941 that his threats against the press in Nigeria were not politically motivated, but followed laid down procedures in the United Kingdom of censoring press material, to prevent leakage of information and suppress rumour mongering. Lord Moyne had consequently directed the government, when dealing with reports of racial discrimination in Nigeria in future to impose censorship, as a last resort, and with the prior approval of the Colonial Office, after the failure of the informal approach (Moyne to Sir Bernard Bourdillon, 22 September 1941) .The West African Pilot on 14 March 1942, thus focused on the position of the British House of Commons that even if the personal approach failed, and constant evasion of the regulations by the press warranted the enforcement of censorship regulations, the governor needed to exercise a very liberal discretion. By implication, the Colonial Office and the British parliament would not approve of the reckless enforcement of press censorship, even in wartime.

Governor Bourdillon complied with the Secretary of State's directive and adopted the informal approach in relating with the press through press conferences, a well known instrument of media control. The Information Office had instituted regular, weekly "informal Saturday chat" with a view to establishing "friendly and regular relations with the press". Unfortunately, the experiment was abandoned after a period of four weeks during which "nobody turned up at all" (NAI, CSO1/32, Ending December, 1942). Press conferences were subsequently 
inaugurated in 1941, with the hope of Nigerian officialdom to "achieve something useful" by providing newspaper editors with the opportunity of discussing difficulties or points they wanted explained, both about the war and Nigerian affairs, generally. Government officials had sought, by this means "to cash in on the apparent willingness of the editors to be reasonable at an informal discussion ..." to gain their cooperation. However, editors refused to be influenced such that "whatever was said or agreed or explained in the informal discussions made not the slightest difference to what was written in the papers". Press conferences were subsequently suspended by the government which considered them "useless". Instead, the colonial regime weighed the option of bringing the press "to book for their offences" by way of "a few healthy fines" (Denton, 1943, No. 103). It is noteworthy that the American press had reacted in a similar manner when Woodrow Wilson instituted "the first regular formal Washington press conferences," leading to his complaint that a majority of the press corps took more interest "in the personal and the trivial rather than in principles and policies" (Krieghbaum, 1968:59).

It suffices to note that persistent demands by Nigerian colonial administrators on government to control the press, and allow officers to institute suits for libel and slander, arising from scurrilous and inaccurate articles about them could not sway adherence to the Colonial Office's directives. Instead, government declared that, other than "its powers of persuasion", it could not "compel articles to be submitted for censorship before publication" (Hoskyns-Abrahall, No. 60/1944). Government disallowed individual officers to institute libel cases against the press because articles which appeared libellous might on closer examination turn out not to be so. In fact, the loopholes in the regulations made them so "difficult more precisely to define", and "not easy to secure sound foundation for action", so journalists could easily circumvent pre-publication censorship (Howe, 21/11/44, C 227 Vol. V).

Indeed, under the restraining influence and ever watchful eyes of the Colonial Office, rigorous press censorship could not be enforced in Nigeria during the war years. At any rate the press recognized the enormous powers conferred on the governor by the Emergency Regulations to severely restrict press freedom, and therefore submitted to the system of voluntary censorship. It thus strove to conduct itself in such a way as not to be rash and tactless so that, as the Daily Service of 18 August 1941 noted, it would not "cause any necessity for official restriction of any kind on our work". This included sending a deputation to the governor and apologizing to aggrieved groups for offending editorials, as was done by the publishers of the Daily Service in 1941. The Daily Service noted on 8 February 1941 that the governor also duly appreciated the importance of "excellent relations between the Press and the Government", and merely admonished offending newspapers "to go 
and sin no more". He thereby secured the cooperation of "even Editors of the most rabid type".

In effect, as in the three decades before the Second World War, the Nigerian press of the World War II era functioned effectively as the main "vehicle of public opinion and the medium of political pressure and propaganda" because, as in the period before World War II, "those who owned and edited them were actively engaged in politics" (Omu, 1974:521-39; Twumasi, 1974:499-501). Besides, as Shaloff (1972) shows with respect to Ghana between 1933 and 1939, the evidence supports the suggestion that in Nigeria during World War II, the Colonial Office and the local administration were seldom in agreement on the question of restricting the freedom of the African press.

\section{Threat of militant nationalism and recourse to enforcement of press censorship}

The seldom agreement between the Colonial Office and the Nigerian Government to restrict the freedom of the press was reached in 1945, when the subtle application of the censorship regulations, under the administration of Henry Bernard Bourdillon (1935-1943), gave way to rabid intolerance of criticism and severe enforcement of press censorship during the governorship of Arthur Frederick Richards(19431947). The government prohibited the publication and printing of the West African Pilot and the Daily Comet, leading members of the Zik Group, between 8 July and 14August 1945. At the end of the European phase of the Second World War, the Nigerian Government had revoked the censorship regulations with effect from 10 May 1945 (Gazette No. 29). However, government re-imposed the regulations on 4 July 1945, barely two weeks into a Nigerian workers' general strike, which lasted for three months from 21 June 1945. The strike arose from government's failure to fulfil its promise in 1942, to grant a wage review that would reflect the cost of living index. Both the West African Pilot and the Daily Comet had justified the workers' action, and enjoined the government to be flexible in dealing with the issue (Azikiwe, 1994).Instead, the government had blamed them for publishing false statements attributed to the Public Relations Officer which the government believed had rubbished its efforts to persuade the workers to end the strike (Public Notice No. 140).

Azikiwe (1994) deployed his professional experience to successfully neutralize the effects of the ban on his newspapers, and further alleged that he had uncovered government's plot to assassinate him. He thereby attracted international attention, and local, popular sympathy. The Nigerian public had not the faintest idea about government's real reasons for banning the publication of the affected newspapers because government was given to too much confidentiality: "too enamoured of the metaphor of a mailed fist in a velvet glove", and thereby left the impression that "the Government will not tolerate the 
criticism of enlightened Africans seeking the progress of Nigeria" (Stanfield, June 1945). Government also declined to renew Azikiwe's Class B Wireless Licence because his claim that the materials provided by Reuters formed the basis of his allegation of government's plot to assassinate him was proved to be baseless (Government Printer, 1946, 24th Session: 13).

The government further prohibited all its functionaries, including Native Administrations from placing government advertisements or notices in all papers in the stable of the Zik Group, with effect from 16 October 1945. The Pilot's privilege of being represented at the Press Table of the Nigeria Legislative Council, was also revoked for distorting the governor's threat to dismiss workers if they participated in future strikes, as well as his assurance that Azikiwe had "nothing more substantial to fear than the dark shadows of his own imagination" (Government Printer, 1946, 23rd Session: 9). The Pilot and Comet had conveyed the erroneous impression "that the Government took a very lenient view about the strikers' action and about the alleged attempt made by certain section of the community to assassinate a journalist during the memorable strike" . The governor rescinded his order on 9 January 1946, when "the paper published a suitable apology", but insisted that until Azikiwe effected "a radical change in his editorial method" he did not "consider that Government's attitude towards his group of papers should be changed" (Richards to Hall, 1946). The colonial government was alarmed over the rising popularity of the papers of the Zik Group because despite official claim that they engaged in a deliberate "campaign of misrepresentations against administrative officers" with an overwhelming "cumulative effect" (Senior Resident Warri, 1944, No. W.P.4227/81), "their readers have implicit faith in the truth of all they publish" (Resident Benin, 1944, No. 14).

Consequently, Governor Richards resolved "to go for Azikiwe" (Pearce, 1981:298), and instituted a libel suit against one of the vibrant editors of the Zik Group of newspapers. A Daily Comet editorial of 9 November 1945, had urged the Colonial Office to investigate Bourdillon, "a poor under-salaried official" for allegedly having so corruptly enriched himself during his tenure as Nigeria's governor that he was worth "over well nigh a million pounds". The editor of the newspaper, Anthony Enahoro(1965), who was subsequently jailed for criminal libel, attributes his conviction to government's strategy to check the slide to civil disobedience, spearheaded by newspaper editors in Nigeria. There was evidence, however, that the editors of the Zik Group had decided to give the "fullest editorial support" and thereby exploit the workers' agitation of 1945 to further the aims of Nigerian nationalism. Enahoro had consequently established contact with the workers and conferred with Herbert Macaulay, president of the NCNC for the purpose of exploiting the "political possibilities" offered by the workers' strike by encouraging them to "hold out to the bitter end", so 
as to merge Nigeria's political with economic struggles. Government effort to checkmate the Zik Group by requiring the West African Pilot and the Daily Comet to submit their editorials for official censorship before publication was rebuffed. Instead of complying, the two newspapers appeared without editorials but with odd quotations designed to infuriate the governor:

BENEATH THE RULE OF MAN ENTIRELY GREAT, THE PEN IS MIGHTIER THAN THE SWORD - EDWARD BULWER-LYTTON THE LIBERTY OF THE PRESS IS THE PALLADIUM OF CIVIL, POLITICAL AND RELIGIOUS RIGHTS - JUNIUS (pp. 79-81).

However, Azikiwe (1994), Enahoro's employer attributes the latter's ordeal "mainly to inexperience", and "the impetuosity of youth egged on by patriots", as well as "ignorance of the fine points of the law of libel". These had made Enahoro "to be decoyed into publishing...criminal libel" against Bourdillon who was generally acclaimed to be "a very considerate, humane and reasonable person and a friend of the African" (302-303; Azikiwe, 1978:2-3).

Obviously, the end of the Second World War, without palpable signs of movement towards colonial freedom had tended to favour the rise of militant nationalism in Nigeria. Governor Richards' appointment from Jamaica, where he had a record of high handedness in dealing with the educated elite was a clear indication that Britain was not prepared for a peaceful transfer of power soon after the war, thereby igniting Nigeria's militant nationalism. The Zik press constituted the instrument which, along with the NCNC and organized labour sought to merge economic with political grievances (Mordi, 2011), to launch Nigeria on the road to independence. In this regard, the press had derived much inspiration from India, which the Nigerian Daily Times of 11 August 1942 publicized the demands of its nationalists for immediate British withdrawal, and thereby focused world attention on the vast colony and dazzled the imagination of the emergent Nigerian elite . Consequently, the West African Pilot which on 13 July 1942 demanded for a democratic Nigeria, on 14 July 1942 expressed a firm belief that "The day of vast empire is past" while "The day of equal peoples is at hand". Thus editors generally splashed stories which they knew to be tendentiously distorted and inaccurate in order not only to boost the circulation of their newspapers but also to project themselves as "young African crusaders against a devilish imperialistic capitalistic government" (Denton, No. 103, 20/4/43).

\section{Conclusion}

At the onset of the Second World War which Allied propagandists had proclaimed was driven by the zeal to defeat Nazism and its inherent doctrine of racial superiority, Imperial Britain imposed checks on the freedom of expression through censorship regulations that foreboded the 
muzzling of press freedom in wartime Nigeria. The censorship regulations had derived its origin and impetus from metropolitan Britain, where it had been formulated and dutifully applied, culminating in the ban on the publication of ten newspapers in the early years of the war. A peculiar Ministry of Information had been established in the metropolitan capital on the declaration of war and saddled with the responsibility of distributing war news and of news censorship. The chaos and confusion that characterized the implementation of its unusual mandate had made the ministry and imperial government the butt of accusations of Gestapo tactics from a section of the press, culminating in the establishment of an independent Censorship Bureau in the metropolitan capital. The regime of press censorship which was imposed in the metropole was extended to colonial Nigeria, with an information officer employed to ensure its enforcement.

The comprehensive press censorship regulations which heralded the onset of the Second World War and presaged a regime of severe press censorship in Nigeria was, therefore, a mere application of an Empire-wide policy to the colony and protectorate of Nigeria. The evidence shows that the severe censorship and rabid intolerance of freedom of expression foreboded by the regulations did not materialize until the end of the European phase of the war when a section of the Nigerian press had sought to exploit economic grievances to mobilize Nigerians for militant nationalism. The Nigerian press had viewed the regulations as a necessary sacrifice for the defeat of Nazism, but exercised some measure of freedom to criticize government policies throughout the duration of the war, while submitting to self-censorship and complying with official directives not to publish sensitive information. It thereby sought to demystify the colonial state and its philosophical underpinning of racial superiority. In its discharge of this function, the press largely successfully resisted official attempts to influence or dictate the content of the news media. Conversely, official reactions to the press' exercise of its privileged freedom, even in wartime were largely within the bounds of the universally accepted principle that the exercise of any right must be in conformity with the law. The dexterity with which the press resisted and circumvented the provisions of the law; and the restraining influence of the Colonial Office safeguarded press freedom during the period, notwithstanding Governor Richards' punitive actions against the Zik Group, late in 1945 when the British Empire and indeed the free world were celebrating the defeat of Nazism. It is hoped that the current study of wartime censorship has brought new insights to the intriguing subject of press controls in important British colonies, and offers a new perspective of British press censorship in Britain and its colonies in periods of emergencies, particularly during the Second World War, using the Nigerian example. 


\section{References}

Agbaje, A. A. B. (1992).

The Nigerian press, hegemony and the social construction of

Anton, C. (n.d)

legitimacy 1960-1983. Lewiston: The Edwin Mellen Press.

The British censorship during the WW2. Available at https://www.historia.ro/sectiune/general/articol/thebritish-censorship-during-the-ww2 (Accessed 26 March 2017).

Azikiwe, N. (1978).

Freedom of the press: A political analysis. Nsukka, University of Nigeria lecture delivered at a symposium under the auspices of the Political Science Association of the University of Nigeria, March 11, 1-20. Mimeo.

Broughton, M. (1961).

Press and politics of South Africa. Capetown: Durnell and Sons.

Brown, W.R. (1944).

[Communication] to Denton, Public Relations Officer, Lagos, 29/6/44. NAI, FIS 1/62 File No 56 Vol. II.

Coker, I. H. E. (1965).

Landmarks of the Nigerian press: An outline of the origins and development of the newspaper press in Nigeria 1959 to 1965.

Lagos, Apapa: Nigerian National Press.

Coleman, J. S. (1958).

Nigeria: Background to nationalism. Berkeley: University of California Press.

Crowder, M. (1974).

The 1939-45 war and West Africa. In J. F. Ade Ajayi and M.

Crowder (Ed.) History of West Africa vol. two. (pp. 596 - 621).

London: Longman Group.

Crowder, M. (1976).

West Africa under colonial rule. Benin City: Ethiope

Publishers.

Denton, H. C. B. (1943)

Assistant Information Officer, Press conferences. National

Archives, Ibadan (NAI), FIS 1/140, No. 103, 20/4/43.

Enahoro, A. (1965).

Fugitive offender: The story of a political prisoner. London.

Cassel.

Ewa, I. O. (1993).

Military recruitment in Eastern Nigeria during the Second

World War. Ife Journal of History, 1(1), 32 - 46.

Government Printer (1940).

The Nigeria defence (Amendment No. 4) regulations 1940.

Lagos: Government Printer. 
Government Printer (1940).

The Nigeria defence (compulsory national service) regulation

1940, No. 33 of 1940. Lagos: Government Printer.

Government Printer (1940).

The prohibition of watch tower publications order in council

1940, No 15 of 1940. Lagos: Government Printer.

Government Printer (1941).

The publications (control of newsprint) regulations 1941. Lagos:

Government Printer.

Government Printer (1943).

Nigeria legislative council debates, twentieth Session, $7^{\text {th }}, 9^{\text {th }}$ and

10 ${ }^{\text {th }}$ September 1943. Lagos: Government Printer.

Government Printer. (1944).

Defence regulations including the Nigeria general defence

regulations 1941 (being regulations made under the emergency

powers (defence) Acts 1939 and 1940, as applied to Nigeria and

consolidated up to and including the 30th day of April, 1944.

(2nd ed.). Lagos: Nigeria Government Printer (Nigerian

National Archives, Ibadan (NAI). GR/X18).

Government Printer (1945).

Nigeria legislative council debates, twenty-third session 1945.

Lagos: Government Printer.

Government Printer (1946).

Nigeria legislative council debates, $24^{\text {th }}$ Session 1946. Lagos:

Government Printer.

Government Printer (1949).

Nigeria legislative council debates, third session, 1949. Lagos:

Government Printer.

Hachten, W. A. (1971).

Muffled drums: The news media in Africa. Ames Iowa: the

Iowa State University Press.

Hoskyns-Abrahall, T. (1944).

Acting Chief Secretary to the Government, NAI, Oyo Prof

2/3 C227 Vol. V. Circular No. 60/1944 of 21 ${ }^{\text {st }}$ December 1944.

Howe, G. L. 91944).

Acting Attorney General The Press: Legal position in relation to press censorship, NAI, Oyo Prof 2/3 C277 Vol. V. 21/11/44. Memorandum.

Ikoli, E. (1950).

The Nigerian press. The West African Review, xxi (273), 625-27.

Irving, H. (2014).

Chaos and censorship in the Second World War. Available at https://history.blog.gov.uk/2014/09/12/chaos-andcensorship/ (Accessed 27 March 2017).

Jones-Quartey, K. A. B. (1965).

A life of Azikiwe. London: Penguin. 
Jose, I. B. (1987).

Walking a tight rope: Power play in Daily Times. Ibadan:

University Press.

Killingray, David (2010).

Fighting for Britain: African soldiers in the Second World War.

Suffolk: James Carrey.

Krieghbaum, Hillier (1968, July 13).

Government media conflict. Saturday Review. pp. 59-60.

Lee, Chin- Chuan (1998).

Press self-censorship and political transition in Hong Kong.

Martin, K. (1947).

The Harvard International Journal of Press/Politics, 3(2), 55-73.

The press the public wants. London: The Hogath Press.

Mendel. T. (n.d).

Restricting freedom of expression: standard and principles,

Background paper for meetings hosted by the UN special rapporteur on freedom of opinion and expression. Centre for Law and Democracy. Available at http://www.lawdemocracy.org/wp-content/uploads/2010/07/10.03.Paperon-Restrictions-on-FOE.pdf (Accessed 26 March 2017)

Mizuno, T. (2011, Spring).

Censorship in a different name: Press supervision in wartime Japanese American camps 1942-1943. Journalism \& Mass Communication Quarterly, 88 (1), 121-141, DOI: 10.1177/107769901108800107.

Mordi, E. N. (1994).

Press and politics in Nigeria 1937-1966 (Nsukka, University of Nigeria, Ph.D. Thesis), Mimeo.

Mordi, E. N. (2002).

The role of the Nigerian press in the industrial relations process in colonial Nigeria 1940-45: A historical perspective. African Journal of Economy and Society, 4(1 \& 2), 22-26.

Mordi, E. N. (2008).

Reconsidering the origins of Nigerian federalism: New insights from the colonial press. In: E. C. Emordi, S. E. Edoko and B. O. Iganiga, (Eds.), Contemporary essays on Nigerian society, economy and law (pp. 99 - 136). Ekpoma: Ambrose Alli University Publishing House.

Mordi, E. N. (2009).

Wartime propaganda, devious officialdom, and the challenge of nationalism during the second world war in Nigeria. Nordic Journal of African Studies, 18 (3), 235-257.

Mordi, E. N. (2011). 
Post-war propaganda as public relations: British containment of militant nationalism in Nigeria, 1945-60.

The International Communication Gazette, 73(3), 198-215.

Mordi, E. N. (2012).

The Nigerian youth movement in crises: New perspectives

from the colonial press. In: Leo E. Otoide, (Ed.) History unlimited: Essays in honor of Professor Abednego Ekoko. (pp. 351-68). Benin City: Mindex Publishing.

Moyne to Sir Bernard Bourdillon 22 September (1941).

Nigeria Secret. NAI, CSO 1/35.

Niven, C. R. to Akintola, S. L.(1956).

The Editor, The Daily Service, Lagos 3rd April No 56/382.

NAI, FIS 1/62 File No. 56 Vol. I

Oduntan, O.B. (n.d.).

Para-colonial newspapers and the shaping of modernity in colonial

Abeokuta. Available at: http:/ / www.uni-

leizig.de/ecas209/index.php?option=com_docmanEtask=doc_downloadEgid

$=1346$ (Accessed 26 April 2015).

Okonkwor, R. C. (1989).

Evolution and dynamics of Nigeria's public

communication system. In Tony Ngbemena, Egerton

Uvieghara \& Didi Uyo (Eds.) Philosophy and dimensions of

national communication policy vol. I. Lagos: Centre for Black

and African Arts and Civilization, 155-168.

Olisa, Michael, S.O., \& Ikejiani-Clark O.M. (Eds.). (1989).

Azikiwe and the African Revolution. Onitsha: Africana-FEP

Publishers.

Omu, F. I. A. (1968).

The dilemma of press freedom in colonial Africa: The West

African example. Journal of African History, 9(2), 279-98.

Omu, F. I. A. (1974 Dec).

Journalism and the rise of Nigerian nationalism: John

Payne Jackson, 1848-1915. Journal of the Historical Society of Nigeria, vii (3), 521 - 39.

Omu, F. I. A. (1978).

Press and politics in Nigeria 1880-1937. London: Longman.

Osuntokun, A. (1979).

Nigeria in the First World War. London: Longman.

Oyemakinde, W. (1974).

Michael Imoudu and the emergence of militant trade

unionism in Nigeria, 1940-42. Journal of the Historical Society of Nigeria, 7(3): 541-561.

Oyemakinde, W. (1975).

The Nigerian general strike of 1945. Journal of the Historical Society of Nigeria, 7(4), 693-710.

Pearce, R. D. (1981). 
Governors, nationalists and constitutions in Nigeria, 193551. Journal of Imperial and Commonwealth Studies, 9(3), 289307.

Propaganda, Encyclopaedia Britannica, 15, pp 36-45.

Report on the activities of the Information Office for the quarter ending 1942. Nigeria dispatches to Secretary of State Nos1-200 4 January-7 May 1943. NAI, CSO 1/32.

Resident Benin Province to the Public Relations Officer, Lagos 13 $3^{\text {th }}$ July 1944. NAI, FIS 1/9 No 14 Vol. II. No. P. 1810/1020.

Richards, A. F. Governor to George Hall, Secretary of State, 3rd April 1946. NAI, CSO 1/32 Nos. 1-32.

Senior Resident Warri Province to the Public Relation Officer, Lagos $10^{\text {th }}$ October 1944. NAI, FIS 1/62 No 56 Vol. II. No. WP. 4227181

Shaloff, S. (1972, July).

Press controls and sedition proceedings in the Gold Coast 1933 - 39. African Affairs, 71(284), 241-63.

Stanfield, (1945, July 31).

District Officer, Oyo Division to the Resident, Oyo Province, Public relations reports for the quarter ending June 1945. NAI, Oyo Prof 2/3 C151.

Stein, M. L. (1968, October 12).

The press under assault. 1, View from the U.S. Saturday Review .pp. 75-76.

Tambini, D. (2012).

The end of press freedom, Oxford: The Foundation for Law, Justice and Society. Available at https://www.fljs.org/files/publication/Tambini.pdf (Accessed 26 March 2017)

Tebbel, John (1968, September 14).

Global freedom of the press: a slow strangulation. Saturday Review. pp. 40-41.

Trewin, Ion (1975).

Journalism, Vancouver: David and Charles.

Twumasi, Y. (1981, January).

Media of mass communication and the 3rd republican constitution in Ghana. African Affairs, 80(318), 13-27.

Twumasi, Y. (1974, Dec).

Press freedom and nationalism under colonial rule in the

Gold Coast (Ghana). Journal of the Historical Society of

Nigeria, 7(3), 499-520. 